\title{
Non-Conventional Tendon Advance for injuries in zones I and II New Surgical Technique
}

\author{
Francisco López Bustos
}

Corresponding Author: Francisco López Bustos,

Received Date: October 12, 2021; Accepted Date: November 22, 2021; Published Date: December 10, 2021

Citation: Francisco López Bustos. (2021) Non-Conventional Tendon Advance for injuries in zones I and II New Surgical Technique. J. Clinical Orthopedics and Trauma Care, 3(1); Doi:10.31579/2694-0248/013

Copyright: @ 2021 Francisco López Bustos, This is an open-access article distributed under the terms of the Creative Commons Attribution License, which permits unrestricted use, distribution, and reproduction in any medium, provided the original author and source are credited.

\section{Abstract \\ Once a primary suture of flexor tendon in zone II of Verdan is unable to be performed, or in those cases in which a re- rupture of a primary tenorraphy occurs, the tendon graft is the goldstandard option.}

Keywords: Non-Conventional Tendon
$9(69,23 \%)$

\section{Introduction}

Once a primary suture of flexor tendon in zone II of Verdan is unable to be performed, or in those cases in which a re-rupture of a primary tenorraphy occurs, the tendon graft is the goldstandard option.

The adherence rates in primary suture, as well as the inherent co-morbilty related to use of tendon grafts whether from the forearm or the foot, are widely known $[1,2,3]$.

The results of these last methods are, in most of their cases, less satisfactory than those in which primary suture is carried out.

Considering these instances, a procedure which dispenses flexor graft is presented.

This technique consist in performing a zetaplasty in zone $\mathrm{V}$ of the proximal stump of the flexor committed, making its progress in that area, and thereby achieving the distal stump to carry out an end to end suture in zone I or II. In case the shortening of the proximal stump is considerable, and thus the end to end suture is unable, we propose to suture then lengthened proximal stump to the nearest uninjured flexor profundus tendon.

In earlier reports from 1950[1] and 1981[1], encouraging results of lengthening of flexor pollicis longus in zone $\mathrm{V}$ for rupture of this tendon are described. Le Viet [1] performed a zetaplasty of profundus flexors in order to achieve a primary suture in cases of retraction of the proximal stump.

In a more recent study [1], these procedures are described just for treatment of jersey finger injuries.

In view that these techniques have been used only for specific cases, we consider important to describe our results in other cases.

\section{Material and Methods}

13 flexor tendon injuries in 13 patients were operated on. were male, and 4 were female. Average age was 29 years (range 20-49 years). Dominant hand was affected in $84,61 \%$ of the cases (11 of 13 cases).

The most affected finger was the little ( 6 cases), followed by the index ( 3 cases). Middle ( 2 cases), and ring ( 2 cases) completed the series.

7 cases constisted of rupture of primary suture of profundus flexor tendon, and the remaining 6 were untreated profundus flexor tendon injuries which had such degree of shrinkage, that make impossible any attempt to carry out an end to end suture.

In 4 cases $(30,77 \%)$ suture of injured collateral nerves was excute. This procedure delayed the rehabilitation period.

In 7 cases tendon advance was performed by zetaplasty in zone $\mathrm{V}$ of the same affected tendon, thus achieving the distal stump to carry out the end to end suture.

In 6 cases in which the shortening of the proximal stump was considerable, a suture of the lengthened proximal stump to the nearest and unscathed profundus flexor tendon was execute.

After surgery, an above elbow cast was used for protection of the suture for 4 weeks.

Rehabilitation exercises began following the removing of the cast, and progressive load was applied to the hand 8 weeks after the surgery.

Strickland punctuation system [2] was used to assess the results.

"Statistical analysis was carried out with an IBM SPSS Statistics 19.0". This analysis was developed with a non-parametric median test.

\section{Results}

Average follow up was 17,23 months (rate 32-6 months).

Tendon progress achieved for the total sample was 20,53 $\mathrm{mm}(12-32$ $\mathrm{mm})$. 
Zetaplasties in zone $\mathrm{V}$ yielded an average advance of $18 \mathrm{~mm}$, whereas the inter-tendon sutures $23,5 \mathrm{~mm}$. These contrasts were statistically significant. $(p=0,029)$.
Regarding the Strickland punctuation, good and excellent results were present in almost all cases.

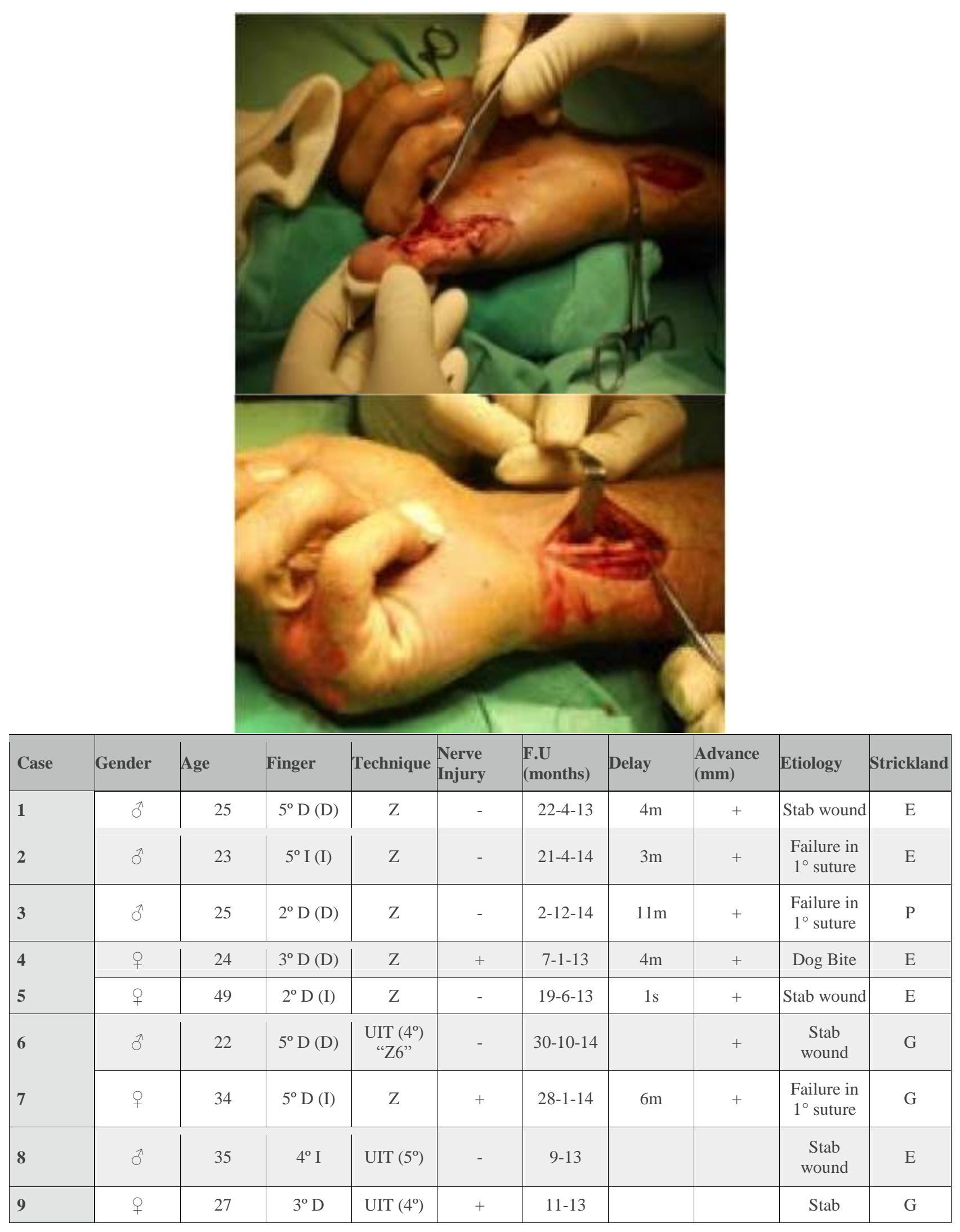




\begin{tabular}{|c|c|c|c|c|c|c|c|c|c|c|}
\hline Case & Gender & Age & Finger & Technique & $\begin{array}{l}\text { Nerve } \\
\text { Injury }\end{array}$ & $\begin{array}{l}\text { F.U } \\
\text { (months) }\end{array}$ & Delay & $\begin{array}{l}\text { Advance } \\
(\mathrm{mm})\end{array}$ & Etiology & Strickland \\
\hline & & & & & & & & & wound & \\
\hline 10 & $\hat{0}$ & 26 & $5^{\circ} \mathrm{D}$ & $\operatorname{UIT}\left(4^{\circ}\right)$ & - & $2-14$ & & & $\begin{array}{c}\text { Stab } \\
\text { wound }\end{array}$ & E \\
\hline 11 & $\hat{0}$ & 35 & $2^{\circ} \mathrm{D}(\mathrm{D})$ & Z & - & $11-11-14$ & $3 m$ & + & $\begin{array}{c}\text { Stab } \\
\text { wound }\end{array}$ & $\mathrm{E}$ \\
\hline 12 & o & 36 & $5^{\circ} \mathrm{D}(\mathrm{D})$ & $\operatorname{UIT}\left(4^{\circ}\right)$ & + & $3-2-15$ & $5 \mathrm{~m}$ & + & $\begin{array}{c}\text { Stab } \\
\text { wound }\end{array}$ & E \\
\hline 13 & 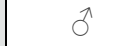 & 20 & $4^{\circ} \mathrm{D}(\mathrm{D})$ & $\operatorname{UIT}\left(3^{\circ}\right)$ & - & $23-1-15$ & $1 \mathrm{~m}$ & + & Avulsion & $\mathrm{G}$ \\
\hline
\end{tabular}

\section{Discussion}

Reconstruction of profundus flexor tendon is indicated in cases of failure of primary repairs, late diagnosis with retraction of proximal stump, and in complex injuries with tissue defect.

Prognosis in reconstructions is determined by the delay in treatment, the rate of tendon retraction, it's blood supply, the soft tissue environment, the indemnity of the superficial flexor tendon, and surgeon's experience.

Surgical options include tendon advance, grafts in one or two procedures, tendon transfers, and silastic prosthesis. Other rescue surgeries include arthrodesis, capsulodesis, and tenodesis, etc.

According to bibliography, grafts in all its variants, are the most popular and the very first chosen. Although, there is not still agreement on which tendon would be the best graft, diameter, length, and resilience must be taken into consideration. The most often used are Flexor Palmaris Brevis, Plantaris, Extensor Digiti Quinti, Extensor Indicis, and Toes Extensors [1, $2,3]$.Allografts have also been proposed [12].

More recently, in a series of 71 cases [13], vascularized tendon grafts have been proposed.

Synthetic implants can be used, provided they are well tolerated [13, 14, $15]$.

Sita and Durand, [16] proposed the reconstruction in zones I and II by transferring a half tendon of the adjacent flexor superficialis tendon.

Regarding tendon lengthening in forearm [6], there have been recent reports. Chanel et al, [7] in 2014 assessed the advance of flexor profundus tendon by performing a zetaplasty as a treatment for the jersey finger. This tendon advance was limited due to presence of the lumbrical muscle and the synovial adherence. No restrictions in the index were reported. Although this technique was proposed for this last pathology, we consider that the zetaplasty might weaken the tendon, and therefore increase the adherence rate.

Any of these procedures needs a very careful technique and an extensive experience in flexor tendon repair.

With regard to this technique, we consider among its advantages, the minor complexity, the lower co-morbidity, and the decrease in surgical time. These benefits might be greater in case more fingers are needed of repair.

The proposed technique can be applied in 1 or two steps.

Since the tendon original blood supply is preserved, and the anatomic diameters of the stumps are similar, the glide through the pulleys shall not be restricted.
A weakness in the tendon after the zetaplasty, which can be reinforced by inter tendon suture, might be a disadvantage of the technique.

We consider that the number of cases is still low, but the short term results encourage continuing to perform this technique regarding its simplicity, low morbidity, and early recovery.

\section{Conclusions}

Proper indications for this new technique of non-conventional tendon advance of the fingers in injuries in zones I and II are: acute and chronic trauma where the retraction of the proximal stumps makes the primary suture unable.

Its versatility lies on the possibility of carrying out an end to end suture of a retracted tendon disregarding a tendon graft. A $\mathrm{Z}$ lengthening is performed in the proximal stump in zone $\mathrm{V}$ so as to suture it to the distal stump, or to attach this last one to the distal phalanx.

We emphasize that the requirement of tendon grafts is left aside, decreasing thereby the morbidity of the procedure.

The need of a second approach in the wrist must be considered, though, in order to carry out the zetaplasty, tendon advance, or inter tendon suture.

The performance in 1 or 2 steps can be determined by the surgeon, provided the presence of adherences, or the requirement of reconstruction of the pulleys.

This new technique is presented as an alternative to the classic option of the tendon grafts in cases of a single or multiple injuries of flexor tendons.

More comparative studies will be needed so as to achieve more definitive conclusions.

\section{References}

1. Finsen V. Two-stage grafting of digital flexor tendons: a review of 43 patients after 3 to 15 years. Scand J Plast Reconstr Surg Hand Surg 2003;37:159-162.

2. LaSalle WB, Strickland JW. An evaluation of the two-stage flexor tendon reconstruction technique. J Hand Surg Am 1983;8:263-267.

3. Boyes JH, Stark HH. Flexor tendon grafts in the fingers and thumb. A study of factors influencing results in 1000 cases. J Bone Joint Surg Am 1971;53:1332-1342.

4. Rouhier G. Restoration of the long flexor tendon of the thumb without sacrificing the primary tendon.J Chir (paris) 1950; 66: 537-542.

5. Vigliani F, Martinelli B. Repair of rupture of flexor pollicis longus by " $Z$ " lengthening at the wrist. Ital J ORthop Traumatol 1981; 7:171-179. 
6. Le Viet D. Flexor tendon lengthening by tenotomy at the musculotendinous junction. Ann Plast Surg 1986;17:239-246.

7. L. Chanel a,*, J.-L. Grolleau a, F. Lauwers b, A. Z-plasty lengthening of the flexor digitorum profundus at the wrist (zone 5) for the treatment of jersey finger Anatomical study and evaluation of advancement obtained. 2014 British Association of Plastic, Reconstructive.

8. Strickland J. W. Results of flexor tendon surgery in zone II. Hand-Clin, 1985 Feb, 1 (1) : 167-179.

9. Wehbe' MA. Tendon graft anatomy and harvesting. Orthop Rev 1994;23:253-256.

10. Carlson GD, Botte MJ, Josephs MS, et al. Morphologic and biomechanical comparison of tendons used as free grafts. J Hand Surg Am 1993;18:76-82.

11. Paneva-Holevich E. Two-stage plasty in flexor tendon injuries of fingers within the digital sinovial sheath. Acta Chir Plast $1965 ; 7: 112-124$.
12. Xie RG, Tang JB. Allograft tendon for second-stage tendon reconstruction. Hand Clin 2012;28:503-509.

13. Guimberteau JC, Bakhach J, Panconi B, Rouzaud S. A fresh look at vascularizedflexor tendon transfers: concept, technical aspects and results. J Plast Reconstr 2007;60(7):793810.Aesthet Surg 2007;60(7):793-810.

14. Hunter JM, Singer DI, Jaeger SH, Mackin EJ. Active tendon implants in flexor tendon reconstruction. J Hand Surg 1988;13A(6):849-859.

15. Hunter JM, Jaeger SH. Tendon implants: primary and secondary usage. Orthop Clin North Am 1977;8(April (2)):473-489.

16. Honner R, Meares A. A review of 100 flexor tendon reconstructions with prosthesis. Hand 1977;9(3):226-231.

17. Laura-Carmen Sita-Alb, MDa, Sébastien Durand, MD. Tendon Reconstruction with Adjacent Finger Hand Tendon., PhDb,* Hand Clin 29 (2013) 243-250.
This work is licensed under Creative Commons Attribution 4.0 License

To Submit Your Article Click Here:

Submit Manuscript

DOI:10.31579/2694-0248/013

\author{
Ready to submit your research? Choose Auctores and benefit from: \\ $>$ fast, convenient online submission \\ $>$ rigorous peer review by experienced research in your field \\ $>$ rapid publication on acceptance \\ $>$ authors retain copyrights \\ $>$ unique DOI for all articles \\ $>$ immediate, unrestricted online access
}

At Auctores, research is always in progress.

Learn more https://auctoresonline.org/journals/clinical-orthopaedics-andtrauma-care 